\title{
Competency-Based Curriculum and Active Methodology: Perceptions of Nursing students
}

\author{
Vania Daniele Paranhos ${ }^{1}$ \\ Maria Manuela Rino Mendes²
}

This study identifies the perceptions of undergraduate students at the University of São Paulo at Ribeirão Preto, Brazil, College of Nursing (EERP-USP) concerning the teachinglearning process in two courses: "Integrated Seminar: Health-Disease/Care Process in Health Services Policies and Organization", which was offered to first-year students in 2005 and 2006 and "Integrality in Health Care I and II", which was offered to second-year students in 2006. The courses' proposal was to adopt active methodology and competencybased curriculum. Data were collected from written tests submitted to 62 students at the end of the curse, focusing on the tests' pertinence, development of performance, structure and pedagogical dynamics, organization and settings. Thematic analysis indicated that students enjoyed the courses, highlighted the role of the professor/facilitator at points of the pedagogical cycle and learning recorded in students' portfolios. Students valued their experience in the Primary Health Care setting, which was based on, and has since the beginning of the program been based on, the theory-professional practice interlocution and closeness to the principles of the Unified Health System (SUS).

Descriptors: Curriculum; Nursing Education; Methodology; Competency-Based Education; Problem-Based Learning.

\footnotetext{
Escola de Enfermagem de Ribeirão Preto, Universidade de São Paulo, WHO Collaborating Centre for Nursing Research Development, Brazil:

${ }^{1}$ Nursing undergraduate student. Scholarship holder, Scientific Initiation Program of the Pro-Rectory of Undergraduate Studies. Universidade de São Paulo, Brazil, e-mail: vaniadaniparanhos@gmail.com.

2 Faculty, e-mail: manu@eerp.usp.br.
}

Corresponding Author: Vania Daniele Paranhos Escola de Enfermagem de Ribeirão Preto. Universidade de São Paulo Avenida dos Bandeirantes, 3900 Bairro Monte Alegre CEP: 14040-902 Ribeirão Preto, SP, Brasil E-mail: vaniadaniparanhos@gmail.com 


\section{Currículo por competência e metodologia ativa: percepção de estudantes de enfermagem}

Objetivou-se identificar a percepção dos estudantes do bacharelado na EERP/USP, sobre o processo de ensino-aprendizagem, nas disciplinas Seminário Integrado: Processo Saúde-Doença/Cuidado na Política e Organização dos Serviços de Saúde, do primeiro ano, em 2005 e 2006, e Integralidade no Cuidado em Saúde I e II, do segundo ano, em 2006, cuja proposta era adotar metodologia ativa e currículo integrado, orientado por competência. Utilizou-se, na coleta de dados, avaliações escritas instituídas, realizadas por 62 estudantes ao final dessas disciplinas, focalizando sua pertinência, desenvolvimento de desempenhos, estrutura e dinâmica pedagógica, organização e cenários. Da análise temática realizada sobre essas avaliações, evidenciou-se que os estudantes gostam das disciplinas, destacaram o papel do professor/facilitador nos momentos do ciclo pedagógico e sua aprendizagem, registrados em portfolio. Valorizaram a experiência em cenário da Atenção Básica à Saúde, baseada na interlocução teórica à prática profissional e aproximação dos pressupostos do SUS, desde o princípio do curso.

Descritores: Currículo; Educação em Enfermagem; Metodologia; Educação Baseada em Competências; Aprendizagem Baseada em Problemas.

\section{Currículo por competencia y metodología activa: percepción de estudantes de enfermería}

Se tuvo por objetivo identificar la percepción de los estudiantes de bachillerato en la EERP/USP, sobre el proceso de enseñanza-aprendizaje, en las disciplinas Seminario Integrado: Proceso Salud-Enfermedad/Cuidado en la Política y Organización de los Servicios de Salud, del primer año, en 2005 y 2006, e Integralidad en el Cuidado en Salud I y II, del segundo año, en 2006, cuya propuesta era adoptar metodología activa y currículo integrado, orientado por competencia. Se utilizó, en la recolección de datos, evaluaciones escritas instituidas, realizadas por 62 estudiantes al final de esas disciplinas, focalizando su pertinencia, desarrollo de desempeños, estructura y dinámica pedagógica, organización y escenarios. Del análisis temático realizado sobre esas evaluaciones, se evidenció el gusto de los estudiantes por esas disciplinas, ellos destacaron el papel del profesor/facilitador en los momentos del ciclo pedagógico y su aprendizaje, registrados en portfolio. Valorizaron la experiencia en el escenario de la Atención Básica a la Salud, basada en la interlocución - de la teoría a la práctica profesional y en la aproximación a las proposiciones del SUS, desde el comienzo del curso.

Descriptores: Curriculum; Educación en Enfermería; Metodología; Educación Basada en Competencias; Aprendizaje Basado en Problemas.

\section{Introduction}

The education of the generalist nurse, capable of working in the complex context of health care, has preoccupied and mobilized Brazilian health professionals who seek to understand the National Curricular Guidelines that focus on a critical-reflexive perspective and competence. From this perspective, the undergraduate teaching coordination at the University of São Paulo at Ribeirão Preto, College of Nursing (EERP/USP) has promoted discussions among faculty members desiring to review the educational process, which culminated in the development of the Undergraduate PoliticalPedagogical Project.

This pedagogical project is based on central concepts of the Brazilian public educational and health policies, whose guiding axes are: primary health care, healthdisease/care process, work process in the production 
of care, pedagogical references of competence and interdisciplinarity, permeated by ethics, teamwork and humanization ${ }^{(1)}$.

The new pedagogical project, focused on a competency-based curriculum and active methodology, resulted from internal and external demands, due to the dissatisfaction with the disciplinary teaching model, lack of connection between basic and professional fields, valorization of the technological and procedural approach in clinical care in the face of the new Guidelines and Bases of the National Education and Undergraduate Nursing Programs ${ }^{(2-3)}$ and public health policies and social responsibilities of public universities.

This new Political-Pedagogical Project provides training linked to the professional world, breaking with the dichotomy between theory and practice so that learning is significant and capable of educating individuals committed to the construction of a healthcare model based on the SUS principles of integrality and humanization ${ }^{(4)}$.

Nursing students are encouraged to reflect on situations experienced in the context of healthcare, to develop skills in integral care focused on individual and collective needs, directed by actions (activities/ tasks) and on meeting individual needs (permeating the life's vital cycle), collective needs, organization and management of care focused on Basic Health Care.

The actions that are part of nurses' role are: to identify health needs (individual and collective), formulate and process health problems, develop, execute and evaluate care plans, participate in the organization and follow-up of the healthcare process, execute the integrated care plan and evaluate health care. Each action requires the use of attributes (knowledge, skills and behaviors) that guide teaching and learning.

The defined actions/tasks direct the development of students' professional performance in a process of action-reflection-action in health care.

The organization of learning experiences in concrete environments where nurses' professional work is carried out is the differential proposed by the new curriculum, which seeks to connect knowledge areas that guide primary health care ${ }^{(5)}$

Students have to integrate information with reflective observation and experimentation with theory, using previous knowledge as a reference point. The ability to think critically is an essential attribute for health professionals, which requires them to become familiar with their object several times, in addition to developing technical aptitude(6).
The selected contexts should allow students to use strategies to immerse in reality in order to experience and reflect on situations that will be recorded as acquired knowledge. The individual or group reflective process that is promoted with the active presence of professors should raise learning questions to guide the search for qualified information so that students can understand reality and ground their actions (tasks). This process directs the return to the setting and transforms actions (enlarged), as evidenced in their performance.

Experiences close to professional practice promote significant learning, the construction of knowledge, skills and attitudes, along with autonomy and responsibility. Such processes must be documented in students' portfolios.

Portfolios activate reflective thinking with records of the learning process evidenced in self-reflection, indications of cues that link with strategies of selfdirection, reorientation and self-development ${ }^{(7)}$.

Students who are encouraged to reflect take the initiative and assume responsibility in a real context of nursing and develop competencies, i.e., the ability to mobilize different skills to deal with situations inherent in professional practice. When students combine attributes - cognitive domain (knowledge), abilities - psychomotor domain (know-how) and attitudes - affective domain (know to be and to live with) it is possible to acquire a broad view of their field of work ${ }^{(8)}$.

Evaluation is a continuous and co-participative process given the students' learning and development, in a small group with pedagogical support. During the realization of actions (tasks) the use of attributes and performance of nurses is acknowledged by the students self-evaluation, and the evaluation of the group and professor.

Students evaluate the course and the professor at the end of the course. This evaluation focuses on the relevance of professional education, contribution to the development of proposed performance through pedagogical activities, organization and settings.

\section{Objective}

To characterize students' perceptions concerning the teaching-learning process in courses based on critical pedagogy, competency and active methodology, included in the pedagogical project implemented in 2005 and offered to first and second-year undergraduate students at EERP/USP. 


\section{Method}

This is a qualitative, descriptive and exploratory study with thematic analysis of empirical data generated by students on the evaluation of the curricular change at the EERP/USP in 2005 and 2006. The project was approved by the Ethics Research Committee at the EERP/USP in July 2007 (Protocol no 0812/2007.)

The undergraduate program at the EERP was defined as the field of this study. The chosen courses that were close to the principles of the competencybased curriculum were: Integrated Seminar: HealthDisease/Care Process in Health Services Policies and Organization offered to first-year students in 2005 and 2006; Integrality in Health Care I (ICI:06) in the first semester and Integrality in Health Care II (ICII:06) in the second semester offered to second-year students in 2006.

The access to empirical material - the tests taken by students of these courses - was authorized by the Undergraduate Office of the EERP.

Meetings with students who registered in 2005 and 2006 were scheduled during the classes' intervals to present the project's objectives and methodology when Free and Informed Consent Forms (FICF) were distributed to each student with one copy for students' information and one for them to sign and indicate their agreement to participate in the study. At the time students were asked to identify themselves in the documents (evaluations of the courses) so we could match these with the signed FICF and randomly define the study's participants. Names are confidential and documents are identified by the courses' acronym and year followed by a number in numerical sequence.

The population was composed of 62 individuals, nine $(11.2 \%)$ from the course SI:05 and 20 (25\%) from SI:06 totaling 29 evaluations from the first year; $12(15 \%)$ from the ICI:06 and 21 (26.2\%) from the ICII:06, totaling 33 from the second year.

Copies of the courses' evaluations, secondary data, were carefully explored. Thematic analysis( ${ }^{(9)}$ proceeded through reading of the material to grasp the meanings that composed the subjects' report. A careful rereading, question by question, was carried out and the diversity of meanings were underlined by pencil until no more new information was found and data saturation was achieved. This stage constituted pre-analysis. Afterwards, data were transcribed and composed, organized into charts to ease analysis of obtained results and their interpretation.
Analysis of empirical data by saturation takes into account one of the limitations of qualitative research, which implies paying attention to the size of the study's universe, that is, reduce the sample to the representative essential set.

\section{Results}

Following, we present the structural elements of the written evaluation, highlighting the courses in the first two years of the program, and illustrations of empirical data of the studied individuals. The students' opinions differed in relation to the learning obtained in SI and ICI and II. They report their first developed communication, observation, writing skills in addition to initiative and data collection skills as evidenced by the reports: we learned to see, listen and feel (SI:06/17); we really learned what health needs were through data collection (SI:06/12).

Unlike what was reported by the SI students ( $1^{\text {st }}$ year), the ICI students and II ( $2^{\text {nd }}$ year) highlighted immersion techniques in different settings, practicing (mainly) individual care, collective care and care organization/management, and improving their knowledge. For example: (...) I've learned techniques that I felt the need to learn and could apply them to improve patients quality of life (...) (ICI:06/10).

Despite the disappointment presented by students in the beginning of the program they indicated that the integrating courses were good. They highly complimented the initiative to put them in contact with health services' users during the first year, e.g.: it permits us to be in touch with people and their problems in the daily routine (SI:06/06).

In relation to the pertinence of the program to the education of nurses, students reported that: the course helps students to develop knowledge, skills and to identify health needs based on their experiences (...) I believe that nurses have to have all these qualities to carry out the profession with quality (...) it shows and exemplifies very well the professional routine (SI:06/06); this course is necessary for the learning of nursing competencies such as knowledge about individual and collective care and management (ICII:06/18).

Reference to the pedagogical process, specifically in learning-teaching activities to favor development of performance is illustrated in: (...) we can form our opinions and our learning (...) performance development is achieved everyday with our experience (SI:05/03); performance can only be developed during immersion, provisory synthesis and discussion of new synthesis (...) practical activities fixed theory and enlarged the evolution of transformation of performance that was observed with our work in household visits and in Basic Health Units (BHU) (ICI:06/02). 
The development of the pedagogical cycle was described as: we searched for data in literature, discussions in research groups made us stronger and more prepared for the next visit (...) all afflictions and doubts were brought to reality (...) an enriching learning that we will take for the rest of our lives and profession (SI:05/01); Immersion in reality: we recognize the environment (community and $\mathrm{BHU}$ ); household visits and experiences in BHU (...); Provisory Synthesis: we would take our activities at the end of each immersion in reality and decided the learning point (...); Search and analysis of information: carried out in a certain time scheduled in the week in a regular and individual way (...); New Synthesis: we discussed learning and each one's findings in the classroom or laboratory (...); Evaluation: was taken at the end of these activities (ICI:06/04).

The classes that attended SI and IC made comments in relation to the structure of courses and evaluated them as disorganized at the beginning of the semester, which improved throughout the semester, for example: in the first semester (...) very disorganized (...) in the second semester it started to make more sense (SI:05/01); the beginning is very difficult (SI:05/02); the course seemed very vague in the beginning, it didn't clarify our doubts, I realized through the course the importance of constructing knowledge in groups (SI:06/05).

The attributes observed in learning-teaching settings used by the integrating courses in the first years were highlighted and students reported the facilitating role of professors, noting tenuous moments when faculty members did not accompany them on household visits or did not interact well with the group: the teaching-learning setting was satisfactory due to the fellowship among the health team members, who helped the group when necessary and trusted in students and facilitators. The previous knowledge of facilitators concerning the field is important because it allows us to organize activities that would be carried out (ICII:06/15).

The evaluation format permitted students to make comments and/or suggestions so they could expose critical perceptions and show commitment to the improvement of the innovating process of nurses' education, though they did not much explore this opportunity. Among the suggestions was the creation of strategies to share experiences among all in the classroom because they worked in small independent groups during the entire course; the lack of time to work on the portfolio was also highlighted: there should be a moment when all groups would meet so they could exchange information and acquired knowledge (SI:06/15); the time to research and develop the portfolio is too short, which hinders our learning (ICII:06/03).

\section{Discussion}

The traditional teaching model is focused on the professor, holding that students have to learn according to the content of classes and generally within large groups. Under an innovating perspective, the new curriculum of the undergraduate program at the EERP/ USP proposes the organization of students into small groups, guided by professors, who facilitate the learningteaching process in which students are the main focus, with a view to form professionals with initiative and responsible behavior in relation to their own learning, with the ability to seek new information and having a constructive critical attitude(10).

The pedagogical proposal that grounds the integrated curriculum oriented by competencies seeks to connect the professors' actions to the teaching proposal, practice to theory, and the educational institution to the community, valuing phenomena that are essential for professional education(11), where interdisciplinary knowledge is applied.

As students enter the university, they are put in contact with the professional practice and the daily routine of health care, which enlarges the classroom environment and provides a concrete view of the health system and its complexity. Thus, theoretical-conceptual knowledge is based on reality and discussions related to it, which is a methodology that uses data collection to understand the health needs of population segments, enlarging the individual approach to the health services organization and management, including the formation of bonds among people in the school and in the contexts where students are immersed.

The integration of teaching and work in a curriculum demands organization of content so that students understand the reasons for actions (tasks), which gives them the opportunity to develop several aptitudes, both theoretical and social, and also allows them to explore themes and problems beyond conventional boundaries of courses and fields of traditional knowledge ${ }^{(8)}$. This way, students become able to develop critical awareness, relating information acquired and assimilated during the program with the applied and recorded re-constructed knowledge.

For the knowledge to be actively processed, students are included in the healthcare context and routine, not only as spectators, but also with members from the health team. Students face situations that permit them to appreciate the real health needs of individuals and communities. Thus, students integrate 
new knowledge into practice through these learning experiences. This process of construction is didactically structured. Students construct their critical-reflective thinking while they are immersed in different scenarios, relating practice to theory they obtain in their research, group discussion and with real healthcare teams.

In this teaching-learning process, evaluation is carried out in a planned schedule following the development of students, allowing them to detect difficulties to be faced during the learning process, focusing on the development of competency and skills ${ }^{(11)}$. It breaks with the traditional objective of knowledge, which is disconnected from its real implementation, aiming only to classify and attribute grades, or only to realize procedures and techniques not bonded to the perception of care needs.

Teaching-learning experiences in real situations favor integrated development of personal attributes in different settings, where the professor acts as facilitator and mediator. In an enlarged conception, competencies connect and integrate results (tasks and exclusion criteria) to attributes mobilized by the student in certain contexts of practice in a movement of action-reflectionaction $^{(8)}$. The studied subjects understand that the courses help them to develop critical thinking and closeness to reality, which are both useful in forming a professional with attributes and competencies that help them to integrate theory with practice.

Because it is an integrated competency-based curriculum, there is a need to provide tools to professors and students to use an active methodology in a significant and qualified manner so that it is linked and committed to a problem-solving capacity in health care situations ${ }^{(10)}$. Therefore, investing in the education of professionals who seek to develop a practice oriented to the health needs of populations and to the exercise of autonomy coupled with investigative thinking, creativity, ability to communicate and a solving-problem capacity, in which work is carried out in an interdisciplinary team, focused on the human being and the profession ${ }^{(11)}$, is needed and urgent.

The re-definition of the students' role in the pedagogical constructivist approach is based on active methodology and on significant learning ${ }^{(8)}$. Under this approach, students construct knowledge integrated with practice and theory in each situation of pedagogical experience, critically recording their impressions in a reflective text, ordered according to the points on the cycle, which composes their portfolio. The portfolio is therefore an important strategy that needs to be improved(10,12).
In the context of this new curriculum, the professor is more than a mere carrier of knowledge. Professors rather assume the role of advisors of learning and teaching and are not only spectators but are also those who realize reciprocal exchanges, favor autonomy and encourage students' critical thinking.

This process, focused on students, involves the effort of professors to encourage the use of reflective writing in the portfolio to stimulate students' active participation in their learning process and during the construction of knowledge, relating theory to practice. Thus, students do not only read about a given subject or mechanically practice procedures, that is, carry out tasks devoid of meaning. Rather, students theorize about what they do and associate the results of their actions with similar previous experiences, constructing knowledge through the significant learning of pedagogical cycles.

\section{Final Considerations}

The construction of this pedagogical process seeks to educate nurses committed to their social role, subjects in life and work, with a generalist, humanist, critical and reflective education, seeking to break with the practice of placing distance between theory and practice, adopting an active methodology of teaching and learning in real contexts.

In the face of this new pedagogical proposal, from the perspective of the integrated curriculum and dialogical competence, it is necessary to involve the community in the school to improve and review its conceptual and methodological bases and also invest in the planning of evaluations, promoting mediation between the work process, teaching and learning.

The analysis shows that students value integrating courses, which are characteristic of the current curricular change. However, in their reflections and critiques they also highlight the differences in the results achieved by the groups in terms of knowledge and learning, due to the diversity of faculty members' backgrounds and their active involvement in the activities and settings of primary health care.

Students reported similar opinions in relation to the poor organization of courses in the first semester, which was improved afterwards, indicating the need for the school to invest in the faculty members' pedagogical training with a view to promote consistency in experiences and improve the use of the portfolio as an instrument of educational evaluation in the teachinglearning process. 
In summary, the importance of an active methodology in the curriculum is evident but there is also the need to make adjustments involving the groups' integration and professors' support considering that students are the main focus of the teaching-learning process.

\section{References}

1. Escola de Enfermagem de Ribeirão Preto/ USP. Projeto políticopedagógico do curso de bacharelado. Ribeirão Preto (SP): Escola de Enfermagem de Ribeirão Preto/ USP; 2004.

2. Diretrizes e Bases da Educação Nacional, Pub. L. no 9394, Seç.1(248):27833-41 (dez. 20, 1996).

3. Diretrizes Curriculares Nacionais para o curso de graduação em Enfermagem. C.N.E./C.E.S. Seç.1:37; Brasília; 2001.

4. Chirelli MQ, Mishima SM. A formação do enfermeiro críticoreflexivo no curso de enfermagem da Faculdade de Medicina de Marília - FAMEMA. Rev Latino-am Enfermagem. 2003 setembrooutubro; 11(5):574-84.

5. Laluna MCMC, Ferraz CA. Compreensão das bases teóricas do planejamento participativo no currículo integrado de um curso de enfermagem. Rev Latino-am Enfermagem. 2003 novembrodezembro; 11(6):771-7.

6. Kostovich CT, Poradzisz M, Wood K, O’Brien KL. Learning style preference and student aptitude for concept maps. J Nurs Educ. 2007 May; 46(5):225-31.
7. Sá-Chaves I. Portfólio reflexivo: estratégia de formação e de supervisão. Formação de professores. Aveiro (BL): Universidade de Aveiro; 2000.

8. Marins JJN, Rego S, Lampert JB, Araújo JGC, organizadores. Educação médica em transformação: instrumentos para construção de novas realidades. São Paulo (SP): Hucitec; 2004. 9. Minayo MCS. O desafio do conhecimento: pesquisa qualitativa em saúde. 9a ed. São Paulo (SP): Hucitec; 2006.

10. Lima VV, Komatsu RS, Padilha RQ. Desafios ao desenvolvimento de um currículo inovador: a experiência da Faculdade de Medicina de Marília. Interface - Comunic, Saúde Educ. 2003 fevereiro; 7(12):175-84

11. Godoy CB. O curso de enfermagem da Universidade Estadual de Londrina na construção de uma nova proposta pedagógica. Rev Latino-am Enfermagem. 2002 julho-agosto; 10(4):596603.

12. Kear ME, Bear M. Using portfolio evaluation for program outcome assessment. J Nurs Educ 2007 March; 46(3):109-14.

Received: Dec. $23^{\text {rd }} 2008$

Accepted: Sep. $3^{\text {rd }} 2009$ 